\title{
Cephalometric predictors of abnormal sella turcica among individuals with Sheehan
}

\section{Syndrome: A case-control study}

\author{
Preditores cefalométricos de sela túrcica anormal entre indivíduos com Síndrome de Sheehan: Um \\ estudo de caso-controle \\ Predictores cefalométricos de silla turca anormal entre individuos con síndrome de Sheehan: Un \\ estudio de casos y controles
}

Received: 04/21/2021 | Reviewed: 04/30/2021 | Accept: 05/01/2021 | Published: 05/15/2021

Adília Mirela Pereira Lima Cid

ORCID: https://orcid.org/0000-0002-0811-5924

Federal University of Ceará, Brazil

E-mail: adiliamirela1@gmail.com

Ana Rosa Pinto Quidute

ORCID: https://orcid.org/0000-0003-1876-6410

Federal University of Ceará, Brazil E-mail: arquidute@gmail.com

Manoel Ricardo Alves Martins

ORCID: https://orcid.org/0000-0001-7272-9552

Federal University of Ceará, Brazil

E-mail: mramartins@gmail.com

Davi de Sá Cavalcante

ORCID: https://orcid.org/0000-0002-9252-8480

Federal University of Ceará, Brazil

E-mail: davidesacavalcante@hotmail.com

Geibson Góis Brito

ORCID: https://orcid.org/0000-0001-5432-7429

Federal University of Ceará, Brazil

E-mail: geibsongois@hotmail.com

Marcela Lima Gurgel

ORCID: https://orcid.org/0000-0001-9978-0542

Federal University of Ceará, Brazil

E-mail: marcela.gurgel@yahoo.com.br

Lúcio Mitsuo Kurita

ORCID: https://orcid.org/0000-0002-9676-4376

Federal University of Ceará, Brazil

E-mail: luciokurita@gmail.com

Paulo Goberlanio de Barros Silva

ORCID: https://orcid.org/0000-0002-1513-9027

Federal University of Ceará, Brazil

E-mail: paulo_goberlanio@yahoo.com.br

Francisco Samuel Rodrigues Carvalho

ORCID: https://orcid.org/0000-0002-3142-1268

Federal University of Ceará, Brazil

E-mail: samuelcarvalho@ufc.br

Fábio Wildson Gurgel Costa

ORCID: https://orcid.org/0000-0002-3262-3347

Federal University of Ceará, Brazil

E-mail: fwildson@yahoo.com.br

\begin{abstract}
The present study aimed to analyze cephalometric predictors of abnormal sella turcica (ST) in Sheehan Syndrome (SS) patients. An observational case-control study was performed with SS volunteers from the Endocrinology and Diabetology Service of the Walter Cantídio University Hospital (Brazil). The sample was composed of 32 patients allocated in two groups: case group (16 adult women diagnosed with SS) and control group (16 healthy individuals matched by sex and age). Analyzes of the linear dimensions (length, diameter, and depth) of the ST on lateral teleradiographies were made using the Radiocef Studio 2 software. The morphological pattern (anterior oblique wall, double floor contour, bridged, irregularities of the dorsal face, pyramidal) was also assessed. The subjects mean age was $65.47 \pm 10.19$ years. SS patients had lower mean length $(\mathrm{p}<0.001)$, width $(\mathrm{p}<0.001)$ and height $(\mathrm{p}=0.033)$ compared to the control group. The presence of morphological alteration of the ST was statistically significant $(\mathrm{p}=$
\end{abstract}


0.009) compared to the controls. The most frequent morphological changes were irregularities of the dorsal face $(37.5 \% ; \mathrm{p}=0.018)$, oblique anterior wall $(12.5 \%)$, double floor contour $(6.3 \%)$, and bridged appearance $(6.3 \%)$. Our study found smaller dimensions and morphological variations of ST in Brazilian SS individuals, highlighting the importance of ST-related imaging screening.

Keywords: Hypopituitarism; Sella Turcica; Radiography dental digital; Maxillofacial abnormalities.

\section{Resumo}

O presente estudo teve como objetivo analisar os preditores cefalométricos de sela túrcica (ST) anormal em pacientes com Síndrome de Sheehan (SS). Foi realizado um estudo observacional caso-controle com voluntários com SS do Serviço de Endocrinologia e Diabetologia do Hospital Universitário Walter Cantídio (Brasil). A amostra foi composta por 32 pacientes alocados em dois grupos: grupo caso (16 mulheres adultas com diagnóstico de SS) e grupo controle (16 indivíduos saudáveis pareados por sexo e idade). As análises das dimensões lineares (comprimento, diâmetro e profundidade) da ST nas telerradiografias laterais foram feitas com o auxílio do software Radiocef Studio 2. O padrão morfológico (parede anterior oblíqua, contorno do assoalho duplo, em ponte, irregularidades da face dorsal, piramidal) também foi avaliado. A média de idade dos sujeitos foi de $65,47 \pm 10,19$ anos. Pacientes com SS apresentaram menor comprimento médio ( $p<0,001)$, largura $(\mathrm{p}<0,001)$ e altura $(\mathrm{p}=0,033)$ em comparação ao grupo controle. A presença de alteração morfológica do TS foi estatisticamente significativa $(\mathrm{p}=0,009)$ em relação aos controles. As alterações morfológicas mais frequentes foram irregularidades da face dorsal $(37,5 \% ; p=0,018)$, parede anterior oblíqua (12,5\%), contorno do piso duplo (6,3\%) e aspecto em ponte $(6,3 \%)$. Nosso estudo encontrou menores dimensões e variações morfológicas de ST em indivíduos brasileiros com SS, destacando a importância do rastreamento por imagem relacionado ao ST.

Palavras-chave: Hipopituitarismo; Sella Turcica; Radiografia dentária digital; Anormalidades maxilofaciais.

\section{Resumen}

El presente estudio tuvo como objetivo analizar los predictores cefalométricos de silla turca anormal (ST) en pacientes con síndrome de Sheehan (SS). Se realizó un estudio observacional de casos y controles con voluntarios con SS del Servicio de Endocrinología y Diabetología del hospital universitario Walter Cantídio (Brasil). La muestra estuvo compuesta por 32 pacientes distribuidos en dos grupos: grupo de casos (16 mujeres adultas diagnosticadas de SS) y grupo de control (16 individuos sanos emparejados por sexo y edad). Los análisis de las dimensiones lineales (longitud, diámetro y profundidad) del ST en telerradiografías laterales se realizaron utilizando el software Radiocef Studio 2. También se evaluó el patrón morfológico (pared oblicua anterior, contorno de doble piso, puenteado, irregularidades de la cara dorsal, piramidal). La edad media de los sujetos fue de 65,47 $\pm 10,19$ años. Los pacientes con SS tenían menor longitud media $(\mathrm{p}<0,001)$, ancho $(\mathrm{p}<0,001)$ y altura $(\mathrm{p}=0,033)$ en comparación con el grupo de control. La presencia de alteración morfológica del ST fue estadísticamente significativa $(\mathrm{p}=0,009)$ en comparación con los controles. Los cambios morfológicos más frecuentes fueron las irregularidades de la cara dorsal $(37,5 \% ; p=0,018)$, pared anterior oblicua $(12,5 \%)$, contorno de doble piso $(6,3 \%)$ y apariencia en puente $(6,3 \%)$. Nuestro estudio encontró dimensiones más pequeñas y variaciones morfológicas de ST en individuos brasileños con SS, destacando la importancia del cribado por imágenes relacionado con ST.

Palabras clave: Hipopituitarismo; Silla Turca; Radiografía dental digital; Anomalías maxilofaciales.

\section{Introduction}

Sheehan's syndrome (SS) is an endocrine disorder known since 1937 when researcher Harold L. Sheehan observed a pattern of partial or total necrosis of the pituitary gland of women who had suffered severe blood loss during or after childbirth as a consequence of heavy bleeding or hypovolemic shock (Sheehan, 1937). During the gestational period, the pituitary gland may double its volume, mainly due to the hyperplasia of the adenohypophysis (Gibbins, Albright \& Rouse, 2013). Thus, it is more susceptible to ischemia damage, as it has a deficient arterial micro-irrigation, with a predominance of venous microirrigation (Karaca et al., 2016).

SS is characterized as a pituitary insufficiency. The loss of gland function decreases, over time, the secretion of hormones such as the adrenocorticotrophic, thyroid-stimulating, luteinizing, follicle-stimulating, cortisol, estradiol, and prolactin. These hormones are associated with bone metabolism, such as growth hormone, which is responsible for maintaining bone mass in adults, regulating bone remodeling (Gokalp et al., 2009). Hormones can change the pattern of bone trabeculation, sometimes causing osteopenia and osteoporosis (Bolanowski, Halupczok \& Jawiarczyk-Przybyłowska, 2015).

The research on the dimensional parameters and morphological pattern of ST in patients with SS through lateral 
teleradiographies is highly relevant and unprecedented. This study hypothesizes that ST-related cephalometric aspects may predict altered dimensions and morphological characteristics in the SS. Thus, this investigation aimed to analyze cephalometric predictors of abnormal ST in SS patients.

\section{Methodology}

\subsection{Study design}

A case-control study was performed with patients previously diagnosed with SS, matched by sex and age with individuals without the disease. In this type of methodological design, a group of patients who have a disease of interest (cases) and a group of individuals without that disease (controls) are recruited for evaluation (Freire \& Pattussi, 2018). In addition, this study followed the Strengthening the Reporting of Observational Studies in Epidemiology guidelines for observational investigations (https://www.strobe-statement.org/).

\subsection{Context}

The subjects with SS were attended at the Endocrinology and Diabetology Service of the Walter Cantídio University Hospital (Brazil). Patients referred to dental examination at the Faculty of Pharmacy, Dentistry, and Nursing of the Federal University of Ceará were invited to participate. All volunteers signed an informed consent document, and the research was in accordance with the Ethics Committee of the Federal University of Ceará (approval number \# 983.022).

\subsection{Volunteers}

The diagnosis of SS was based on a classic obstetric history (presence of postpartum hemorrhage or obstetric complications) and the presence of hormone deficiency in replacement. The patients could not have any other endocrinopathy associated with SS. The sample consisted of 16 individuals with SS registered at the Endocrinology and Diabetes outpatient clinic of the Walter Cantídio University Hospital (Brazil), aged between 49 and 86 years, with a mean of $65.47 \pm 10.19$ years. For each case, a volunteer without SS or systemic or endocrinopathy changes that could interfere bone metabolism was matched by sex and age. All selected patients already had lateral teleradiographies, as they were patients from the medical/dental complex of the Walter Cantídio University Hospital (Brazil).

\subsection{Variables}

The variables assessed in this study were the linear measurements and morphological analysis of ST. Linear measures (length, diameter, and depth) were measured using the methods of Silverman (1957) and Kisling (1966) (Silverman, 1957; Niswander, 1967). All reference lines used in the present study were located in the mid-sagittal plane. The morphological analysis was classified according to the standards: (a) normal, (b) double contour of the floor, (c) oblique anterior wall, (d) bridge, (e) irregularity on the dorsal surface, and (f) pyramidal shape (Figure 1) (Axelsson, Storhaug \& Kjaer, 2004). 
Figure 1. ST morphology on lateral head teleradiographies: standard shape (A), double contour of the floor (B), anterior oblique wall (C), bridge appearance (D), irregular shape on the dorsal surface (E), pyramidal shape (F).

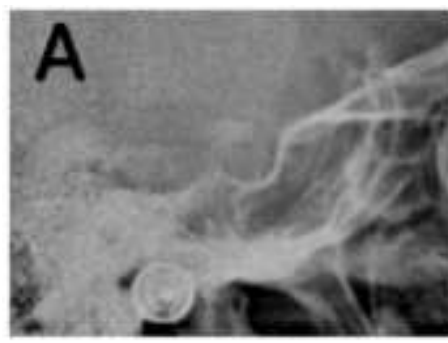

NORMAL

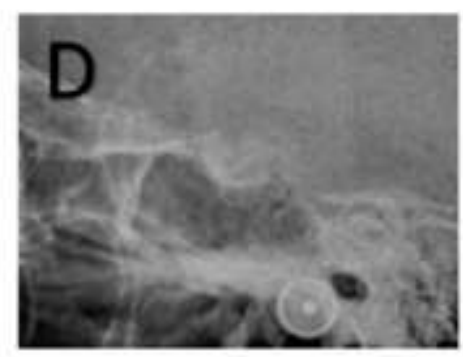

BRIDGE

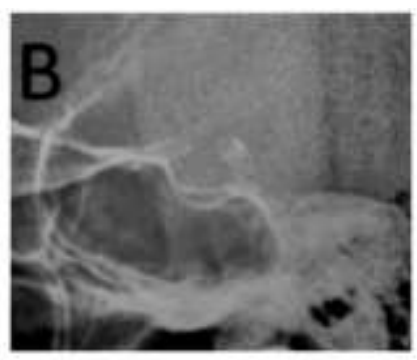

DOUBLE CONTOUR OF THE FLOOR

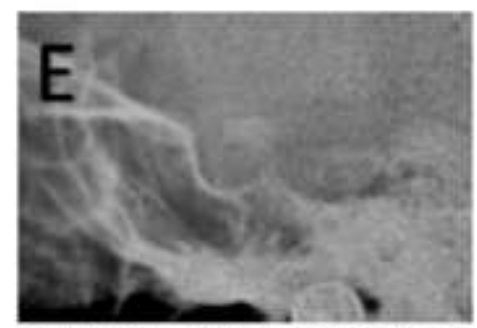

IRREGULAR SHAPE ON THE DORSAL SURFACE

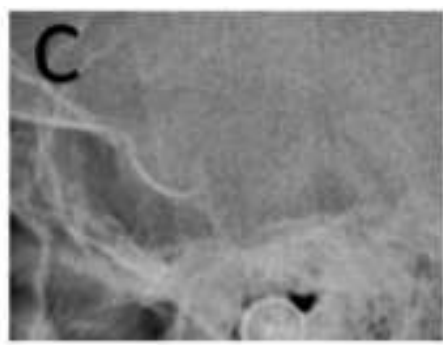

ANTERIOR OBLIQUE WALL

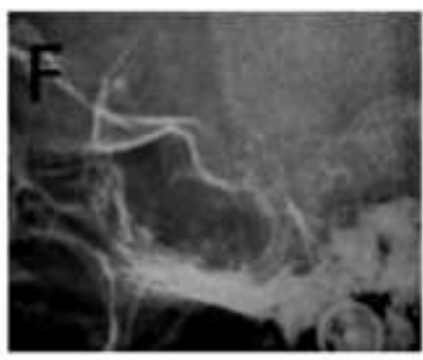

PYRAMIDAL

Source: Authors.

\subsection{Data sources /Measurements}

The digital lateral teleradiographies were obtained using the Kodak K9000 3D equipment (Kodak Dental Systems, Carestream Health, Rochester, NY, USA) belonging to the UFC Dentistry course, with a 14-bit grayscale (16384 tons), kilovoltage, and milliamperage adjusted according to the size of each patient with an exposure time ranging from 0.4 to 1.6 seconds. For radiographic taking, patients were positioned upright, and their heads were positioned correctly on the cephalostat and oriented horizontally in the Frankfurt plane, with the teeth in Maximum Habitual Intercuspidation (MHI). The teleradiographies were exported in Tagged Image File Format - Image File Format with Tags (TIFF) and evaluated in a dark and quiet room, using the Adobe Photoshop CS5 program (Adobe Systems Incorporated, USA), where they were calibrated at 300 dpi. TS morphology analyzes were performed for each patient. The teleradiographies were exported to the Radiocelf Studio 2 software (Radiomemory, Belo Horizonte-MG), where they were calibrated at 300 dpi. Linear measurements of ST were performed for each SS or control patient.

\subsection{Reliability}

All analyses were performed by two examiners during three consecutive days and repeated within 15 days to ensure the reliability and agreement of the measurements. To assess reproducibility errors, (Harris \& Smith, 2009) the following analyzes were performed: (1) Cohen's kappa test for categorical data; (2) intraclass correlation coefficient (ICC) to assess systematic errors regarding numerical data; (3) Dahlberg's formula to assess casual errors in the measurements made.

\subsection{Statistical analysis}

Data were submitted to the Kolmogorov-Smirnov normality test and analyzed using Student's t-test, unpaired or paired ANOVA followed by the Bonferroni post-test and correlation of Pearson (parametric data) or Chi-square/Fisher's exact (categorical data). After categorizing patients, data were compared between the two groups using Fisher's exact test and 
Pearson's chi-square test or Mann-Whitney test (nonparametric data) using the SPSS 20.0 software (p <0.05). In addition, a ROC curve was obtained for the diagnosis of SS based on the measures of the ST, with cutoff points to estimate sensitivity, specificity, positive and negative predictive values, and accuracy.

\section{Results}

Regarding the study reliability, ST-related length, width, and height showed ICC values of $0.92(95 \% \mathrm{CI}=0.82-0.97)$, $0.86(95 \% \mathrm{CI}=0.68-0.95)$ and $0.93(0.84-0.97)(\mathrm{p}<0.001)$. Dahlberg's coefficients for these measures were 2.08, 0.77, and 0.47 , respectively.

The mean age of the individuals was $65.47 \pm 10.19$ years. SS patients had lower mean length $(\mathrm{p}<0.001)$, diameter $(\mathrm{p}$ $<0.001)$ and height $(\mathrm{p}=0.033)$ compared to the control group. In both groups, the width and height did not differ significantly but were greater than the length $(\mathrm{p}<0.001)$ (Figure 2).

Figure 2. ST morphometric data characterization.
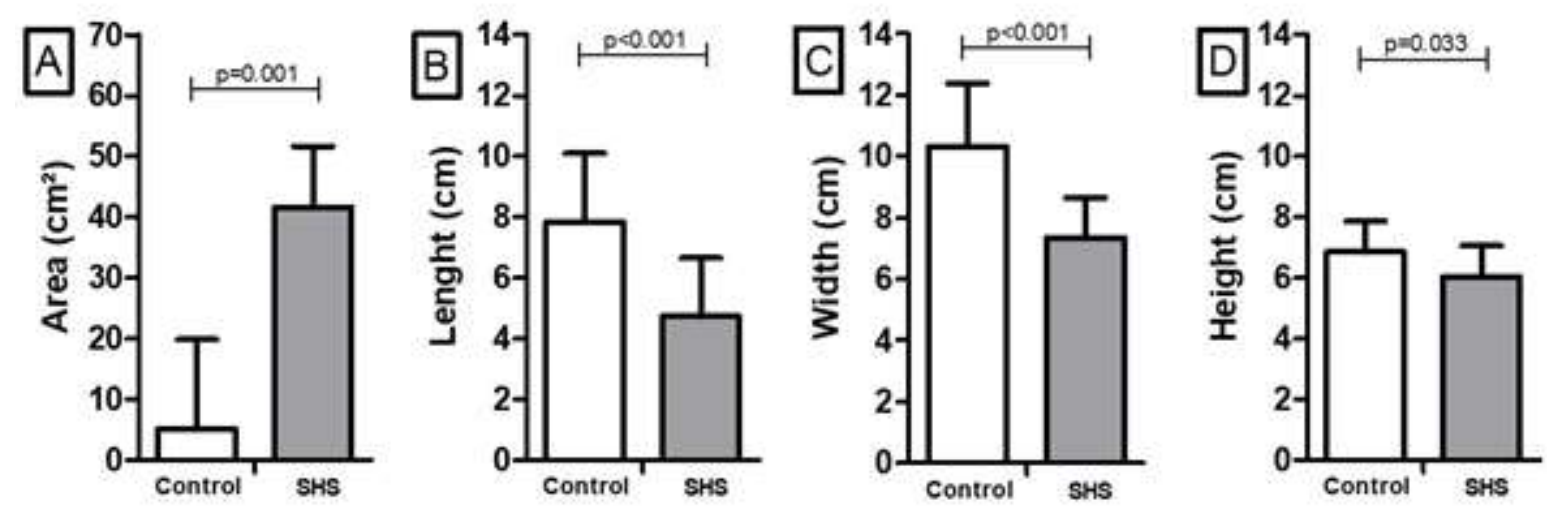

Source: Authors.

Regarding cephalometric analysis-based skeletal classification in individuals with SS, Class I patients presented the width and height of the ST significantly higher than the length $(\mathrm{p}=0.024)$. In Class II patients, there was no difference between measures ( $\mathrm{p}=0.198)$, with ST showing a more spherical shape characteristic in these SS patients. In Class III patients, only the width was significantly higher than the length $(\mathrm{p}=0.004)$, which resulted in an oval ST for this skeletal classification (Table 1).

Table 1. ST measurements according to skeletal class in patients with SHS.

\begin{tabular}{lcccc}
\hline & \multicolumn{3}{c}{ Skeletal class } & \\
\cline { 2 - 4 } & Class I (n=6) & Class II & Class III & \multirow{2}{*}{ p-Value $^{\mathbf{a}}$} \\
\hline Lenght (cm) & & $(\mathbf{n = 3})$ & $(\mathbf{n = 7})$ & 0.978 \\
Width (cm) & $4.73 \pm 0.90$ & $4.94 \pm 0.82$ & $4.64 \pm 2.89$ & 0.400 \\
Height (cm) & $7.88 \pm 1.63^{*}$ & $7.44 \pm 1.35$ & $6.87 \pm 0.92 *$ & 0.067 \\
p-Value & $6.76 \pm 0.94^{\mathrm{b}}$ & $5.97 \pm 1.09$ & $5.46 \pm 0.79$ & $\mathbf{0 . 0 0 4}$ \\
\hline
\end{tabular}

Source: Authors. 
In patients with SS, ST width $(\mathrm{p}=0.012)$ and height $(\mathrm{p}=0.015)$ were directly correlated with the area of the sella. Furthermore, ST width and height $(\mathrm{p}=0.001)$ correlated with each other measurement (Table 2).

Table 2. Correlation between ST measurements and cephalometric variables in SHS.

\begin{tabular}{|c|c|c|c|c|c|c|c|c|c|c|c|}
\hline & & \multicolumn{4}{|c|}{ ST measurements } & \multicolumn{6}{|c|}{ Cephalometric variables } \\
\hline & & & & & & & Mand. & Mand. & & & \\
\hline & & & & & & Max. & Ramus & Corpus & & & \\
\hline & & Area & Lenght & Width & Height & Length & Height & Lenght & SNA & SNB & ANB \\
\hline \multirow[t]{2}{*}{ Area $\left(\mathrm{cm}^{2}\right)$} & $\mathrm{r}$ & - & 0.374 & $0.610^{*}$ & $0.596^{*}$ & -0.143 & 0.365 & 0.245 & 0.155 & 0.200 & 0.093 \\
\hline & $\mathrm{p}$-Valor & - & 0.153 & 0.012 & 0.015 & 0.597 & 0.165 & 0.361 & 0.567 & 0.459 & 0.733 \\
\hline \multirow[t]{2}{*}{ Lenght (cm) } & $\mathrm{r}$ & - & - & 0.479 & 0.054 & -0.189 & 0.384 & -0.127 & 0.220 & 0.232 & -0.065 \\
\hline & p-Valor & - & - & 0.060 & 0.843 & 0.484 & 0.142 & 0.640 & 0.413 & 0.386 & 0.810 \\
\hline \multirow[t]{2}{*}{ Width $(\mathrm{cm})$} & $\mathrm{r}$ & - & - & - & $0.748^{*}$ & -0.112 & 0.480 & 0.102 & 0.004 & -0.090 & 0.190 \\
\hline & p-Valor & - & - & - & 0.001 & 0.681 & 0.060 & 0.707 & 0.989 & 0.741 & 0.481 \\
\hline \multirow[t]{2}{*}{ Height $(\mathrm{cm} 0$} & $\mathrm{r}$ & - & - & - & - & -0.111 & 0.293 & 0.099 & 0.094 & -0.011 & 0.357 \\
\hline & p-Valor & - & - & - & - & 0.683 & 0.271 & 0.715 & 0.730 & 0.967 & 0.175 \\
\hline
\end{tabular}

*ANOVA / Bonferonit test; b ANOVA test for repeated measures / Bonferroni; * p <0.05 versus length (mean \pm SD); Max., maxilla; Mand., mandible. Source: Authors.

The establishment of cutoff points to estimate SS based on the measurements of the ST showed high areas under the ROC curve that were statistically significant for sella area $(\mathrm{p}<0.001)$, length $(\mathrm{p}<0.001)$, width $(\mathrm{p}<0.001)$, and height $(\mathrm{p}=$ 0.035). Cut points of $50 \mathrm{~cm}^{2}$ (area), $6.5 \mathrm{~cm}$ (length), $8.5 \mathrm{~cm}$ (width), and $6.5 \mathrm{~cm}$ (height) were defined as suggestive points for SS diagnosis according to ST analysis on lateral cephalometric exams since they showed reasonable values of sensitivity, specificity, and accuracy (>80\%) (Table 3$)$.

Table 3. ROC characteristics and diagnostic measures in SHS.

\begin{tabular}{lllll}
\hline & Area $\left(\mathbf{c m}^{2}\right)$ & Lenght $(\mathbf{c m})$ & Width (cm) & Height (cm) \\
\hline ROC curve & & & & $0.72 \pm 0.09$ \\
Area under the ROC curve & $0.84 \pm 0.07$ & $0.90 \pm 0.06$ & $0.90 \pm 0.06$ & 0.035 \\
p-Value* & $<0.001$ & $<0.001$ & $<0.001$ & $<6.5$ \\
Cutoff & $<50.0$ & $<6.5$ & $<8.5$ & 0.824 \\
p-Value ${ }^{\dagger}$ & 1.000 & 1.000 & 1.000 & $68.8 \%$ \\
Diagnostic measures & & & & $56.3 \%$ \\
Sensitivity & $75.0 \%$ & $81.3 \%$ & $81.3 \%$ & $61.1 \%$ \\
Specificity & $75.0 \%$ & $87.5 \%$ & $81.3 \%$ & $64.3 \%$ \\
Positive Predictive Value & $75.0 \%$ & $86.7 \%$ & $81.3 \%$ & $62.5 \%$ \\
Negative Predictive Value & $75.0 \%$ & $82.4 \%$ & $81.3 \%$ & \\
Acuracy & $75.0 \%$ & $84.4 \%$ & & \\
\hline
\end{tabular}

$* \mathrm{p}<0.05$, area under the ROC curve $(\mathrm{H} 1 \neq 0) ; \uparrow \mathrm{p}<0.05$, McNemar's test. Source: Authors.

Compared to controls, the presence of morphological alteration of the TS of individuals with SS was statistically 
significant $(\mathrm{p}=0.009)$. The most frequent morphological alterations of ST in women with SS were irregularities of the dorsal face $(p=0.018)$. Ponticulos ponticus was found in $37.5 \%$ of SS individuals, equally distributed between incomplete and complete types (Table 4).

Table 4. Comparison of ST morphological aspects between control and SHS groups.

\begin{tabular}{llll}
\hline & Group & \\
\cline { 2 - 3 } & Control & SHS & p-Value \\
\hline Morphological alteration & $2(12.5 \%)$ & $10^{*}(62.5 \%)$ & $\mathbf{0 . 0 0 9}$ \\
Oblique anterior wall & $0(0 \%)$ & $2(12.5 \%)$ & 0.484 \\
Double floor contour & $2(12.5 \%)$ & $1(6.3 \%)$ & 1.000 \\
Bridge appearance & $0(0 \%)$ & $1(6.25 \%)$ & 1.000 \\
Irregularity of the dorsal wall & $0(0 \%)$ & $6 *(37.5 \%)$ & $\mathbf{0 . 0 1 8}$ \\
Ponticulos ponticus & $1(6.25 \%)$ & $6(37.5 \%)$ & 0.083 \\
Ponticulos ponticus type & & & \\
\multicolumn{1}{l}{ Incomplete } & $0(0 \%)$ & $3(18.75 \%)$ & 1.000 \\
$\quad$ Complete & $1(6.25 \%)$ & $3(18.75 \%)$ & \\
\hline
\end{tabular}

$* \mathrm{p}<0.05$, chi-square or Fisher's exact test. Source: Authors.

\section{Discussion}

Cephalometric analyzes are essential tools in the craniofacial description. In the field of dentistry-related imaging science, this is the first study with SS patients that evaluated morphologic and morphometric aspects among these patients.

The size of the pituitary gland, which controls the body's endocrine functions, is also affected by the morphometry of the ST (Kjaer et al., 1999). Dimensional changes in the ST are associated with several developmental anomalies (Kjaer et al., 1999; Kjær, 2015). Any change in the development of the pituitary gland can affect the size and shape of the ST (Kjær, 2015). The growth of ST is completed in early childhood, and several studies use dimensions and morphology of ST to assess facial direction and growth (Kjaer et al., 1999; Abdel-Kaderm, 2007). Thus, the shape and size of ST gain importance under some clinical conditions, such as SS, Type I Diabetes, Turner Syndrome, Fragile X Syndrome, Trisomy 21, Kallmann Syndrome, Type I Neurofibromatosis, Meckel - Gruber Syndrome, and Williams Syndrome (Kjær, 2015; Diri H et al., 2014; Friedrich et al., 2017; Kjaer et al., 1998).

Regarding the linear dimensions of ST, several studies have shown that there are variations in its morphology throughout 8growth and development (Björk \& Skieller, 1983; Axelsson et al., 2005; Alkofide, 2007). The study by Otuyemi et al. showed a statistically significant difference between young adults and adolescents only for measuring the depth of the ST, demonstrating more significant bone resorption at the base of the ST with increasing age (Otuyemi, Fadeju \& Adesina, 2017). Preston (Preston, 1979) brought similar findings, showing a close correlation between the area of the ST and age. Our study sample was composed of individuals aged between 49 and 86 years, with an average of $65.47 \pm 10.19$, outside the age range where dimensional changes are related to growth and development. Regarding the morphological analysis of ST, studies that evaluated individuals with Down Syndrome (DS) are well addressed in the literature (Suri, Tompson \& Cornfoot, 2010; Korayem \& AlKofide, 2015). In analyzes using lateral radiographs, as in our approach, normality of ST was found less frequently. The most frequent abnormality was an oblique anterior wall. Irregularity in the dorsal wall and pyramidal shape was present in some individuals with DS (Korayem \& AlKofide, 2015). Irregularity of the dorsal face $(37.5 \% ; \mathrm{p}=0.018)$ and an oblique anterior wall (12.5\%) were morphological patterns found in our study. A previous investigation performed a case 
review on the normal and pathological development of ST and pituitary gland in humans. The shape of the ST of individuals with Chondrodystrophy, enlarged and with an irregular internal contour, and Hydrocephalus subjects, who had a wide and abnormal posterior wall, did not present any connection between the anterior and posterior walls, was described (Kjaer et al., 1997). Unlike the results of our study, individuals with SS had statistically significant variations in the morphological pattern.

Despite the correlation between the pituitary gland and the ST in several syndromes, there are still controversies about how this interaction occurs. Smaller ST size plays a critical risk factor to the occurrence of SS. During the gestational period, the pituitary increases the sella size due to intense hormonal activity. Then, the compression and ischemia of the ST, due to lack of space, may predispose to SS development. Thus ST could be a predictor of the syndrome instead of an etiological fator (Bakiri et al., 1991).

\section{Conclusion}

The present study is innovative in analyzing cephalometric predictors of ST abnormalities in patients with SS. This investigation found smaller linear dimensions of length, diameter, depth, and morphological variations for patients with SS compared to healthy patients, highlighting the importance of teleradiographic evaluation in individuals with SS since ST is easily identified in such exams commonly requested in Dentistry. In addition, we strongly recommend future studies for the imaging evaluation of maxillomandibular repercussions from endocrine diseases, such as those related to the ST.

\section{Acknowledgments}

The Brazilian National Council for Scientific and Technological Development (CNPq) provided to Dr. FWGC a PQ fellowship in category 2.

\section{References}

Abdel-Kader, H. M. (2007). Sella turcica bridges in orthodontic and orthognathic surgery patients. A retrospective cephalometric study. Aust Orthod J, 23, 305.

Alkofide, E. A. (2007). The shape and size of the sella turcica in skeletal Class I, Class II, and Class III Saudi subjects. Eur J Orthod, 29 , 457-63.

Axelsson, S., Storhaug, K.,\& Kjaer, I. (2004). Post-natal size and morphology of the sella turcica. Longitudinal cephalometric standards for Norwegians between 6 and 21 years of age. Eur J Orthod, 26, 597-604.

Axelsson, S., Kjaer, I., Heiberg, A., Bjørnland, T., \& Storhaug, K. (2015). Neurocranial morphology and growth in Williams sy ndrome. Eur J Orthod, 27, 3247.

Bakiri, F., Bendib, S. E., Maoui, R., Bendib, A., \& Benmiloud M. (1991). The sella turcica in Sheehan's syndrome: computerized tomographic study in 54 patients. J Endocrinol Invest, 14, 193-6.

Björk, A., \& Skieller, V. (1983). Normal and abnormal growth of the mandible. A synthesis of longitudinal cephalometric implant studies over a period of 25 years. Eur J Orthod, 5, 1-46.

Bolanowski, M., Halupczok, J., \& Jawiarczyk-Przybyłowska, A. (2015). Pituitary disorders and osteoporosis. Int J Endocrinol, $2015,206853$.

Diri, H., Tanriverdi, F., Karaca, Z. Senol, S., Unluhizarci, K., \& Durak, A. C., et al. (2014). Extensive investigation of 114 patients with Sheehan's syndrome: a continuing disorder. Eur J Endocrinol, 171, 311-8.

Freire, M. C. M., \& Pattussi, M. P. (2018). Tipos de estudos. IN: Estrela, C. Metodologia científica. Ciência, ensino e pesquisa. $3^{\mathrm{a}}$ ed. Porto Alegre: Artes Médicas, 109-127.

Friedrich, R. E., Baumann, J., Suling, A., \& Scheuer, H. T. (2017). Sella turcica measurements on lateral cephalograms of patients with neurofibromatosis type 1. GMS Interdiscip Plast Reconstr Surg DGPW, 6, Doc05.

Gibbins, K. J., Albright, C. M., \& Rouse, D. J. (2013). Postpartum hemorrhage in the developed world: whither misoprostol? Am J Obstet Gynecol, 208, 1813.

Gokalp, D., Tuzcu, A., Bahceci, M., Arikan, S., Ozmen, C. A., \& Cil, T. (2009). Sheehan's syndrome and its impact on bone mineral density. Gynecol Endocrinol, 25, 344-9. 
Research, Society and Development, v. 10, n. 5, e52210515316, 2021

(CC BY 4.0) | ISSN 2525-3409 | DOI: http://dx.doi.org/10.33448/rsd-v10i5.15316

Harris, E. F., \& Smith, R. N. (2009). Accounting for measurement error: a critical but often overlooked process. Arch Oral Biol, 54, Suppl 1, S107-17.

Karaca, Z., Laway, B. A., Dokmetas, H. S., Atmaca, H., \& Kelestimur, F. (2016) Sheehan syndrome. Nat Rev Dis Primers, $2,16092$.

Kjaer, I., Becktor, K. B., Nolting, D., \& Fischer Hansen, B. (1997). The association between prenatal sella turcica morphology and notochordal remnants in the dorsum sellae. J Craniofac Genet Dev Biol, 17, 105-11.

Kjaer, I., Keeling, J. W., Reintoft, I., Nolting, D., \& Fischer Hansen, B. (1998). Pituitary gland and sella turcica in human trisomy 21 fetuses related to axial skeletal development. Am J Med Genet, 80, 494-500.

Kjaer, K. W., Hansen, B. F., Keeling, J. W., Nolting, D., \& Kjaer, I. (1999). Malformations of cranial base structures and pituitary gland in prenatal Meckel syndrome. APMIS, 107, 937-44.

Kjær, I. (2015). Sella turcica morphology and the pituitary gland-a new contribution to craniofacial diagnostics based on histology and neuroradiology. Eur $J$ Orthod, 37, 28-36.

Korayem, M., \& AlKofide, E. (2015). Size and shape of the sella turcica in subjects with Down syndrome. Orthod Craniofac Res, 18, 43-50.

Niswander, J. D. (1967). Cranial morphology in Down's syndrome. A comparative roentgenencephalometric study in adult males. Am J Hum Genet, $19,180$.

Otuyemi, O. D., Fadeju, A. D., \& Adesina, B. A. (2017). A Cephalometric analysis of the morphology and size of sella turcica in Nigerians with normal and bimaxillary incisor protrusion. J West Afr Coll Surg, 7, 93-111.

Preston, C. B. (1979). Pituitary fossa size and facial type. Am J Orthod, 75, 259-63.

Sheehan, H. (1937). Postpartum necrosis of the anterior pituitary. J Pathol Bact, 45, 189-214.

Silverman, F. N. (1957). Roentgen standards fo-size of the pituitary fossa from infancy through adolescence. Am J Roentgenol Radium Ther Nucl Med, 78, 451-60.

Suri, S., Tompson, B. D.,\& Cornfoot, L. (2010). Cranial base, maxillary and mandibular morphology in Down syndrome. Angle Orthod, 80, 861-9. 